\title{
Posterior Stabilization for Management of Neglected Odontoid Fractures
}

\author{
Mohammed Attia, Alaa Rashad \\ Neurosurgery Department, Faculty of Medicine, Al-Azhar University, Cairo, Egypt \\ Email: mohameddr594@gmail.com, alaarashad81@yahoo.com
}

How to cite this paper: Attia, M. and Rashad, A. (2021) Posterior Stabilization for Management of Neglected Odontoid Fractures. Open Journal of Modern Neurosurgery, 11, 73-89.

https://doi.org/10.4236/ojmn.2021.112009

Received: February 22, 2021

Accepted: April 5, 2021

Published: April 8, 2021

Copyright $\odot 2021$ by author(s) and Scientific Research Publishing Inc. This work is licensed under the Creative Commons Attribution International License (CC BY 4.0).

http://creativecommons.org/licenses/by/4.0/

\begin{abstract}
Background: Odontoid fractures are specific types of cervical fractures that show many challenges in their management. There are several types of Odontoid fractures with different modes of stability. There is no definite widely accepted way of management of Type II fractures among spine surgeons. There is a high rate of delayed or non-union of Odontoid fracture cases that are managed conservatively which may lead to dangerous complications. If non-union occurs, the patient should undergo surgical intervention as early as possible to avoid neurological deterioration. Objective: To demonstrate the value of intra-operative reduction and posterior stabilization of atlanto-axial junction in cases of non-union old Odontoid fractures and their outcome. The study was also to check for criteria associated with a favorable outcome and if posterior decompression will be associated with a better outcome. Patients and Methods: 12 patients of old neglected Odontoid fractures following conservative management and complicated by non-union were operated through intra-operative reduction with posterior stabilization and fixation of atlanto-axial junction at Al-Azhar University Hospitals during the period starting from June 2016 till the end of December 2019 using Screws and Rods. Intra-operative reduction under C-Arm X-ray and firm stabilization were aimed in all cases. Posterior cord decompression was an option in selected 4 patients with severe cord compression. Both intra-operative, postoperative radiological and clinical outcomes were assessed. Results: Good intra-operative reduction and alignment of fractured Odontoid process were obtained in all cases with use of 4 screws and 2 rods $(2$ screws and 1 rod on each side) in 11 cases and with using 2 screws and 1 rod (unilateral fixation) in one case. Good clinical outcome was obtained in all patients with improvement of pre-operative condition except in 3 patients where there were persistent pre-operative neurological deficits and without deterioration of pre-operative condition. Additional posterior cord decompression was associated with a better clinical outcome in 2 of 4 selected cases with severe cord compression. Conclusion: Good intra-operative reduction under C-Arm $\mathrm{X}$-ray with posterior stabilization through atlanto-axial fixation using screws
\end{abstract}


and rods is a reliable way of management of neglected type II Odontoid fractures complicated with non-union. Better results were obtained with less pre-operative neurological deficits and with absence of myelomalacia in MRI images. Additional posterior decompression may improve clinical outcome in cases of severe cord compression.

\section{Keywords}

Spine, Odontoid Fractures, Non-Union, Posterior Stabilization

\section{Introduction}

Odontoid fractures are specific types of cervical fractures that need special ways of management. Odontoid fractures are mostly occurring following Road Traffic Accidents especially in young adults and following Falls especially in the elderly population. They may be sequelae of chronic diseases like Rheumatoid arthritis. Odontoid fractures are most commonly occurring in elderly patients aging 70 to 80 years [1] [2] [3] [4]. The distribution of Odontoid fractures is equal in both male and female population. They occur mostly following cervical spine hyperflexion or hyperextension [5]. They constitute about $9 \%-15 \%$ of fractures of cervical spines in adult population [6].

The clinical picture of patients with Odontoid fractures ranges from asymptomatic up to quadriplegia with affection of respiratory muscles. Patients are usually having cervical pain with limitation of movement of the neck. Patients look as they are holding their heads with their hands in a trial to support the head and prevent its movement. Neurological affection ranges between $2 \%$ $27 \%$ in most studies. Significant signs are caused by cord affection and nerve roots affection causing different motor and sensory deficits [3] [4]. Odontoid fractures are classified according to Anderson and D'Alonzo classification into 3 types. In Type I, there is an oblique fracture through the upper part of the Odontoid process, while in Type II, there is a fracture at the base of the Odontoid process at its attachment to the body of the axis. In Type III, there is extension of the fracture through the body of second cervical vertebra (C2) [7]. Diagnosis of the type of Odontoid fracture can be done by different radiological methods [8].

Type II fracture is the most common type of Odontoid fracture. It occurs in more than $60 \%$ of cases. It usually occurs below the level of the transverse ligament and it is relatively unstable [9] [10].

Management options differ according to the type of the fracture. Type I and type II can be managed conservatively by external immobilization with a collar or a halo or surgically through either anterior or posterior stabilization [7]. There is still no widely accepted definite treatment option in cases of Type II fractures [5].

There are some limitations of Anderson and D'Alonzo classification. They include "shallow" or "high" Type III fracture which is Type II fracture extending 
inferiorly where surgical fixation is advised by some surgeons as the treatment of choice [11]. In such cases, it is advised to look for involvement of the superior articular facets of 2nd cervical vertebra (C2). If the facet of C2 is not involved, it is considered Type II fracture while if there is involvement of one or two articular facets of C2, it will be considered as Type III fracture [12]. Another limitation is the difficult differentiation between different shapes of the fractures [5]. Type II-A fracture was added by Hadley et al. in which there is addition of chip-fracture fragment at the anterior or posterior aspect of the Odontoid. This type usually progresses to non-union and should be managed surgically [13]. Grauer et al. classified Type II fractures into Type II-A, II-B and II-C and each of which has a specific treatment option [9].

Non-union of Odontoid fractures is usually seen with increased age of the patient, increased fracture displacement extent, fracture comminution, with delayed diagnosis and can occur solely in Type II-A fracture described by Hadley et al. [10] [13]. If fracture non-union occurs, there will be high risk of spinal instability and subsequent spinal cord injury. However, surgical options have possible risks and complications. So, the best way of management should be determined by the ability to obtain proper fusion either by non-rigid immobilization or by surgical fusion [14].

In this study, our aim was to manage patients with non-union Odontoid fractures following failed external immobilization with intra-operative fracture reduction under C-Arm followed by posterior stabilization by screws and rods and to determine the clinical and radiological outcome. Searching for conditions associated with a better outcome was another aim of the current study.

\section{Patients and Methods}

This study was conducted on 12 patients admitted and operated at Al-Azhar University Hospitals with a diagnosis of old neglected Odontoid fractures following different causes during the period starting from June 2016 till the end of December 2019.

Inclusion Criteria included Patients with Type II Odontoid fractures. Only old neglected fractures were included in this study. To be considered neglected old fractures, one-year duration from occurrence of the fracture or onset of the disease was considered the lowest cutoff point. Included patients should be previously managed conservatively with external immobilization and complicated with non-union. Different duration more than one year from the onset of the condition were included in the study. Both males and females were included. All age groups were included.

Exclusion Criteria included: Type I, Type III and recent Odontoid fractures. Patients complicated by mal-union were also excluded.

The study was approved by Ethical Committee of Neurosurgery Department, Faculty of Medicine, Al-Azhar University. Ethical approval was for patient confidentiality. Data collection was done without identification of patients.

For all patients, good history taking followed by full general and neurological 
examination was done to assess the neurological status of the patient. All patients were investigated by X-ray cervical spine to check for evidence of subluxation, CT scan to check for bony fractures, assess the type of fracture and presence or absence of subluxation and associated callus. MRI of the cervical spines was done for all patients to determine associated ligamentous injuries, disc prolapse, cord compression or evidence of myelomalacia. Full laboratory investigations were done for pre-operative preparation.

In all study patients, there were clinical and radiological evidences of atlanto-axial subluxation. They had progressive neurological deterioration and/or persistent cervical pain with radiological evidence of Odontoid fracture non-union and evidence of instability. All of them were candidates for surgical intervention after weighing the benefit/risk ratio of surgical intervention.

All data were recorded in patients' hard medical records and saved also as soft copies on the neurosurgery department electronic filing system at Al-Azhar University Hospitals.

Collection of Data of this study patients were obtained from both medical records of these patients and from Neurosurgery Department electronic filing system at Al-Azhar University Hospitals.

\subsection{Consent}

All study patients or their first-degree relatives if children were informed about the details of the patient condition, the surgical procedure, its suspected benefits and complications, available other surgical and conservative alternatives and their limitations and post-operative suspected rehabilitative measures. They signed a detailed consent before proceeding to the procedure.

\subsection{Surgical Procedure}

The used surgical procedure in this study was intra-operative reduction under C-Arm X-ray together with posterior atlanto-axial stabilization. Our goal with this procedure was to maintain a solid and constant fusion between $1^{\text {st }}$ and $2^{\text {nd }}$ cervical vertebrae ( $\mathrm{C} 1$ and $\mathrm{C} 2)$. In this procedure, Prone position was used to perform the surgical intervention. Exposure of the upper cervical spines was done posteriorly. Under C-Arm Guidance, polyaxial screws were inserted into the lateral mass of $\mathrm{C} 1$ and the pedicles of $\mathrm{C} 2$ with strict precautions to avoid injury of neurovascular structures. After proper insertion of screws, in selected cases, posterior decompression of the cord was done by spinolaminectomy of $\mathrm{C} 2$ and decompression of posterior arch of $\mathrm{C} 1$. Then, proper reduction of $\mathrm{C} 1$ relative to $\mathrm{C} 2$ was done under the Guidance of C-Arm X-ray machine followed by insertion of one suitable rod on each side and then fixing the rods against screws using the suitable nuts. Insertion of 2 screws and one rod on each side was done in all patients except in one patient where unilateral insertion of screws and rod was done. In this study, there was no use of known skeletal traction methods for reduction of the fractured Odontoid. After ensuring good reduction and stabilization in C-Arm images, proper hemostasis and wound closure were done. 


\subsection{Post-Operative}

For all patients, Philadelphia cervical collar was used for 1-month post-operatively in a continuous manner. Then patients were allowed for intermittent use for other 2 weeks with follow up radiological investigations to check for achievement of fusion and state of screws and rods. Post-operative re-assessment of the clinical condition was done. Early post-operative follow up X-ray and CT cervical spine were done for all patients to ensure adequate reduction and stabilization of the fracture with adequate placement of screws. Patients were followed clinically for their neurological condition and their pain. They were also followed radiologically for stability of atlanto-axial fusion. Clinical and Radiological re-assessment were done at 3, 6 and 12 months post-operatively.

\section{Results}

This study included 12 patients. Table 1 shows the clinical criteria, radiological findings and outcome of the current study patients. The study patients' age was ranging between 13 - 64 years with a median age of 42 years. They were 7 males (58.3\%) and 5 females (41.7\%). All patients had neglected Type II Odontoid fractures complicated by non-union. 11 patients were caused by traumatic injury; 7 of them were due to falls (58.3\% of total study cases), 4 were due to previous road traffic accidents (33.4\% of total study cases) and 1 patient was due to Rheumatoid arthritis ( $8.3 \%$ of total study cases) (Table 2 ). The duration between occurrence of Odontoid fracture and surgical procedure ranged between 1 and 3 years with a median of 1.79 years. 5 patients ( $41.7 \%$ of total study cases) were complaining of cervical pain and without neurological deficits; 5 patients $(41.7 \%$ of total study cases) were complaining of weakness of 4 limbs of varying degrees and 2 patients ( $16.6 \%$ of total study cases) were complaining of sensory symptoms. Pre-operative radiological findings showed no evidence of cord compression in 4 patients (33.3\% of total study cases), upper cord compression with no evidence of myelomalacia in 5 patients (41.7\% of total study cases) and cord compression with associated myelomalacia in 3 patients (25\% of total study cases). Posterior cord decompression was done in 4 selected patients (33.3\% of total study patients) with severe cord compression in an attempt to improve the clinical post-operative outcome while in the other 8 patients (66.7\% of total study patients), posterior decompression was not performed. Rheumatoid arthritis patient had severe cord compression and was candidate for posterior decompression. However, the posterior segment was kept after finding the osteoporotic and weak bones on left side of $\mathrm{C} 1$ and $\mathrm{C} 2$ to provide more stability. Good reduction and alignment of fractured Odontoid process were obtained in 11 cases $(91.7 \%$ of study cases) and was fair (partial) in one patient (Rheumatoid arthritis patient) (8.3\% of study cases). Good alignment and reduction were obtained using 4 screws and 2 rods ( 2 screws and 1 rod on each side) in 11 patients $(91.7 \%$ of total study cases) and with unilateral fixation using only 2 screws and 1 rod in one patient (8.3\% of total study cases). Criteria of good results included good clinical and radiological outcome. Good clinical outcome was considered if there 
Table 1. Clinical picture, radiological findings and outcome of the study patients.

\begin{tabular}{|c|c|c|c|c|c|c|c|c|c|}
\hline \multirow{3}{*}{$\begin{array}{c}\text { Case } \\
\text { number }\end{array}$} & \multirow{3}{*}{ Age } & \multirow{3}{*}{ Sex } & \multicolumn{5}{|c|}{ Clinical Presentation } & \multirow{3}{*}{$\begin{array}{l}\text { Radiological } \\
\text { findings }\end{array}$} & \multirow{3}{*}{$\begin{array}{c}\text { Clinical and } \\
\text { Radiological } \\
\text { Outcome }\end{array}$} \\
\hline & & & \multirow[b]{2}{*}{ Duration } & \multirow{2}{*}{$\begin{array}{l}\text { Cause of } \\
\text { fracture }\end{array}$} & \multirow[b]{2}{*}{ Symptoms } & \multicolumn{2}{|c|}{ Signs } & & \\
\hline & & & & & & $\begin{array}{l}\text { Neurological } \\
\text { Deficits }\end{array}$ & Others & & \\
\hline 1 & $\begin{array}{c}13 \\
\text { years }\end{array}$ & Male & 2 years & $\begin{array}{l}\text { Falling from } \\
\text { height }\end{array}$ & $\begin{array}{l}\text { Chronic neck } \\
\text { pain, limited } \\
\text { neck } \\
\text { movement }\end{array}$ & No & $\begin{array}{l}\text { Limited } \\
\text { neck } \\
\text { movement }\end{array}$ & $\begin{array}{l}\text { Fracture odontoid } \\
\text { Type II with } \\
\text { atlanto-axial } \\
\text { subluxation and } \\
\text { No evidence of } \\
\text { myelomalacia. }\end{array}$ & $\begin{array}{l}\text { - Improved } \\
\text { neck pain } \\
\text { - Good } \\
\text { alignment } \\
\text { and fusion, } \\
\text { No implant } \\
\text { failure }\end{array}$ \\
\hline 2 & 30 ys & Female & 2 years & $\begin{array}{l}\text { Road Traffic } \\
\text { Accident with } \\
\text { suspected } \\
\text { hyperextension } \\
\text { injury }\end{array}$ & $\begin{array}{l}\text { Cervical pain, } \\
\text { Progressive } \\
\text { heaviness } \\
\text { of } 4 \text { limbs }\end{array}$ & $\begin{array}{l}\text { Weakness of } \\
4 \text { limbs of } \\
\text { pyramidal } \\
\text { distribution } \\
\text { Grade } 3 / 5 \text { with } \\
\text { hyperreflexia } \\
\text { and +ve } \\
\text { Babiniski sign } \\
\text { bilateral }\end{array}$ & $\begin{array}{l}\text { Limited } \\
\text { neck } \\
\text { movement }\end{array}$ & $\begin{array}{l}\text { Fracture odontoid } \\
\text { Type II with upper } \\
\text { cord compression } \\
\text { and associated } \\
\text { myelomalacia }\end{array}$ & $\begin{array}{l}\text { - Improved neck } \\
\text { pain with } \\
\text { stationary } \\
\text { course of } \\
\text { weakness } \\
\text { - Good } \\
\text { alignment } \\
\text { and fusion, } \\
\text { No implant } \\
\text { failure }\end{array}$ \\
\hline 3 & 45 ys & Male & 1 year & $\begin{array}{l}\text { Pathological } \\
\text { due to } \\
\text { Rheumatoid } \\
\text { Arthritis }\end{array}$ & $\begin{array}{l}\text { Neck pain and } \\
\text { progressive } \\
\text { heaviness } \\
\text { of } 4 \text { limbs }\end{array}$ & $\begin{array}{l}\text { Weakness of } \\
4 \text { limbs of } \\
\text { pyramidal } \\
\text { distribution } \\
\text { Grade } 4 / 5 \text { with } \\
\text { hyperreflexia } \\
\text { and +ve } \\
\text { Babiniski } \\
\text { sign bilateral }\end{array}$ & $\begin{array}{l}\text { Limited } \\
\text { neck } \\
\text { movement }\end{array}$ & $\begin{array}{l}\text { Fracture odontoid } \\
\text { Type II with upper } \\
\text { cord compression } \\
\text { and associated } \\
\text { myelomalacia. } \\
\text { There was mild } \\
\text { Rheumatoid } \\
\text { pannus. Cord } \\
\text { compression was } \\
\text { mainly due to } \\
\text { atlanto-axial } \\
\text { subluxation rather } \\
\text { than Rheumatoid } \\
\text { pannus. }\end{array}$ & $\begin{array}{l}\text { - Improved neck } \\
\text { pain with } \\
\text { stationary } \\
\text { course of } \\
\text { weakness } \\
\text { - Fair alignment } \\
\text { and fusion but } \\
\text { with loosening } \\
\text { of screws at } \\
\text { follow up } \\
\text { radiology at } \\
12 \text { months. }\end{array}$ \\
\hline 4 & 27 ys & Male & 2.5 years & $\begin{array}{l}\text { Falling from } \\
\text { height }\end{array}$ & $\begin{array}{l}\text { Neck pain } \\
\text { and tilt of the } \\
\text { neck to Rt side }\end{array}$ & No & Torticollis & $\begin{array}{l}\text { Fracture odontoid } \\
\text { Type II with No } \\
\text { cord compression }\end{array}$ & $\begin{array}{l}\text { - Improved } \\
\text { neck pain and } \\
\text { torticollis } \\
\text { - Good } \\
\text { alignment } \\
\text { and fusion, } \\
\text { No implant } \\
\text { failure }\end{array}$ \\
\hline 5 & 51 ys & Male & 3 years & $\begin{array}{l}\text { Road Traffic } \\
\text { Accident }\end{array}$ & $\begin{array}{l}\text { Neck pain } \\
\text { and tilt of } \\
\text { the neck to } \\
\text { Lt side with } \\
\text { spino-thalamic } \\
\text { pain }\end{array}$ & $\begin{array}{l}\text { Hypoesthesia } \\
\text { of } 4 \text { limbs }\end{array}$ & Torticollis & $\begin{array}{l}\text { Fracture odontoid } \\
\text { Type II with upper } \\
\text { cord compression } \\
\text { with No evidence } \\
\text { of myelomalacia }\end{array}$ & $\begin{array}{l}\text { - Improved neck } \\
\text { pain, torticollis, } \\
\text { spinothalamic } \\
\text { pain and } \\
\text { hyposthesia } \\
\text { - Good } \\
\text { alignment } \\
\text { and fusion, } \\
\text { No implant } \\
\text { failure }\end{array}$ \\
\hline
\end{tabular}




\begin{tabular}{|c|c|c|c|c|c|c|c|c|c|}
\hline 6 & 28 ys & Female & 2 years & $\begin{array}{l}\text { Falling from } \\
\text { height }\end{array}$ & $\begin{array}{l}\text { Neck pain } \\
\text { with heaviness } \\
\text { of } 4 \text { limbs of } \\
\text { progressive } \\
\text { course. }\end{array}$ & $\begin{array}{l}\text { Weakness of } \\
4 \text { limbs of } \\
\text { pyramidal } \\
\text { distribution } \\
\text { Grade } 2 / 5 \text { with } \\
\text { hyperreflexia } \\
\text { and +ve } \\
\text { Babiniski } \\
\text { sign bilateral }\end{array}$ & $\begin{array}{l}\text { Limited } \\
\text { neck } \\
\text { movement }\end{array}$ & $\begin{array}{l}\text { Fracture odontoid } \\
\text { Type II with upper } \\
\text { cord compression } \\
\text { and No evidence } \\
\text { of myelomalacia }\end{array}$ & $\begin{array}{l}\text { - Improved neck } \\
\text { pain and } \\
\text { weakness of } \\
\text { limbs } \\
\text { - Good } \\
\text { alignment } \\
\text { and fusion, } \\
\text { No implant } \\
\text { failure }\end{array}$ \\
\hline 7 & 35 ys & Male & 1 year & $\begin{array}{l}\text { Falling from } \\
\text { height }\end{array}$ & $\begin{array}{l}\text { Neck pain } \\
\text { and numbness } \\
\text { sensation of } \\
4 \text { limbs. }\end{array}$ & $\begin{array}{l}\text { Hypoesthesia } \\
\text { of } 4 \text { limbs }\end{array}$ & $\begin{array}{l}\text { Limited } \\
\text { neck } \\
\text { movement }\end{array}$ & $\begin{array}{l}\text { Fracture odontoid } \\
\text { Type II with upper } \\
\text { cord compression } \\
\text { and No evidence } \\
\text { of myelomalacia }\end{array}$ & $\begin{array}{l}\text { - Improved neck } \\
\text { pain and } \\
\text { hyposthesia } \\
\text { - Good } \\
\text { alignment } \\
\text { and fusion, } \\
\text { No implant } \\
\text { failure }\end{array}$ \\
\hline 8 & $57 \mathrm{ys}$ & Female & 2 years & $\begin{array}{l}\text { Falling down } \\
\text { following } \\
\text { sliding }\end{array}$ & $\begin{array}{l}\text { Mild chronic } \\
\text { neck pain }\end{array}$ & No & $\begin{array}{l}\text { Limited } \\
\text { neck } \\
\text { movement }\end{array}$ & $\begin{array}{l}\text { Fracture odontoid } \\
\text { Type II with No } \\
\text { cord compression }\end{array}$ & $\begin{array}{l}\text { - Improved } \\
\text { neck pain } \\
\text { - Good } \\
\text { alignment } \\
\text { and fusion, } \\
\text { No implant } \\
\text { failure }\end{array}$ \\
\hline 9 & 63 ys & Male & 1 year & $\begin{array}{l}\text { Road Traffic } \\
\text { Accident }\end{array}$ & $\begin{array}{l}\text { Chronic } \\
\text { cervical pain }\end{array}$ & No & $\begin{array}{l}\text { Limited } \\
\text { cervical } \\
\text { movement }\end{array}$ & $\begin{array}{l}\text { Fracture odontoid } \\
\text { Type II with No } \\
\text { cord compression }\end{array}$ & $\begin{array}{l}\text { - Improved } \\
\text { neck pain } \\
\text { - Good } \\
\text { alignment and } \\
\text { fusion, No } \\
\text { implant failure }\end{array}$ \\
\hline 10 & 33 ys & Female & 1.5 years & $\begin{array}{l}\text { Falling from } \\
\text { height }\end{array}$ & $\begin{array}{l}\text { Neck pain with } \\
\text { heaviness of } \\
4 \text { limbs of } \\
\text { progressive } \\
\text { course. }\end{array}$ & $\begin{array}{l}\text { Weakness of } \\
4 \text { limbs of } \\
\text { pyramidal } \\
\text { distribution } \\
\text { Grade } 2 / 5 \text { with } \\
\text { hyperreflexia } \\
\text { and +ve } \\
\text { Babiniski sign } \\
\text { bilateral }\end{array}$ & $\begin{array}{l}\text { Limited } \\
\text { neck } \\
\text { movement }\end{array}$ & $\begin{array}{l}\text { Fracture odontoid } \\
\text { Type II with upper } \\
\text { cord compression } \\
\text { with No associated } \\
\text { myelomalacia }\end{array}$ & $\begin{array}{l}\text { - Improved neck } \\
\text { pain and } \\
\text { weakness of } \\
\text { limbs } \\
\text { - Good } \\
\text { alignment and } \\
\text { fusion, No } \\
\text { implant failure }\end{array}$ \\
\hline 11 & 64 ys & Male & 2 years & $\begin{array}{l}\text { Road Traffic } \\
\text { Accident }\end{array}$ & $\begin{array}{l}\text { Neck pain } \\
\text { with heaviness } \\
\text { of } 4 \text { limbs of } \\
\text { progressive } \\
\text { course. }\end{array}$ & $\begin{array}{l}\text { Weakness of } \\
4 \text { limbs of } \\
\text { pyramidal } \\
\text { distribution } \\
\text { Grade } 4 / 5 \text { with } \\
\text { hyperreflexia } \\
\text { and +ve } \\
\text { Babiniski sign } \\
\text { bilateral }\end{array}$ & $\begin{array}{l}\text { Limited } \\
\text { neck } \\
\text { movement }\end{array}$ & $\begin{array}{l}\text { Fracture odontoid } \\
\text { Type II with upper } \\
\text { cord compression } \\
\text { and associated } \\
\text { myelomalacia }\end{array}$ & $\begin{array}{l}\text { - Improved neck } \\
\text { pain with } \\
\text { stationary } \\
\text { course of } \\
\text { weakness } \\
\text { - } \text { Good } \\
\text { alignment and } \\
\text { fusion, No } \\
\text { implant failure }\end{array}$ \\
\hline 12 & 58 ys & Female & 1.5 years & $\begin{array}{l}\text { Falling down } \\
\text { while walking }\end{array}$ & $\begin{array}{l}\text { Chronic } \\
\text { cervical pain }\end{array}$ & No & $\begin{array}{l}\text { Limited } \\
\text { cervical } \\
\text { movement }\end{array}$ & $\begin{array}{l}\text { Fracture odontoid } \\
\text { Type II with No } \\
\text { cord compression }\end{array}$ & $\begin{array}{l}\text { - Improved } \\
\text { neck pain } \\
\text { - Good } \\
\text { alignment and } \\
\text { fusion, No } \\
\text { implant failure }\end{array}$ \\
\hline
\end{tabular}


Table 2. Causes of odontoid fractures of study patients.

\begin{tabular}{ccc}
\hline Cause of odontoid fracture & Number of patients & Percentage \\
\hline Falling in hyperextension & 7 & $58.3 \%$ \\
Road Traffic Accidents & 4 & $33.4 \%$ \\
Pathological & 1 & $8.3 \%$ \\
\hline
\end{tabular}

was no deterioration of pre-operative neurological status and improvement of cervical pain and neurological deficits. Good radiological outcome was obtained when there was good alignment and fusion. Improvement of cervical pain with no deterioration of neurological status was obtained in all study patients in the study ( $100 \%$ of study cases). There was improvement of neurological status at follow up at 3, 6 and 12 months post-operative in 4 of 7 patients with pre-operative neurological deficits $(57.14 \%$ of patients with pre-operative neurological deficits). However, there was a stationary course of pre-operative neurological deficits in 3 of 7 patients with pre-operative neurological deficits ( $42.86 \%$ of patients with pre-operative neurological deficits) (Table 3). All 3 patients with no post-operative improvement were those patients with pre-operative motor weakness Grade 3/5 and 4/5 and those with myelomalacia seen in their MRIs. So, there was a strong correlation between post-operative suspected improvement and the lower grade of weakness and with absence of myelomalacia in MRI images. There was improvement in the clinical outcome in 2 patients of 4 patients underwent posterior decompression while no evident improvement was noticed in the other 2 patients. Radiological re-assessment at 3, 6 and 12 months showed proper reduction and fusion of atlanto-axial junction in 11 patients $(91.7 \%$ of total study cases) and evidence of loosening of screws in 1 patient (8.3\% of total study cases) after 1 year. This patient was the Rheumatoid arthritis patient with unilateral fixation and the patient refused both anterior decompressive surgery and Redo surgery for more aggressive posterior fixation and fusion and he preferred to be kept in cervical collar rather than surgical intervention (Table 4).

\subsection{Peri-Operative Complications}

There were no recorded intra-operative or early post-operative complications in all study patients. There was an abnormal finding intra-operatively in 1 patient (Rheumatoid arthritis patient) which was softening and osteoporosis of bones of $\mathrm{C} 1$ and C2 on Left side with difficult safe insertion of the screws and fearing of development of late dangerous complications by screws. So, the patient was operated by one side fixation with aiming to do $2^{\text {nd }}$ surgery after follow up but the patient refused re-surgery. Late post-operative complication was seen also in the same patient which was loosening of screws inserted for unilateral fixation of $\mathrm{C} 1$ - C2 noted at follow up radiology done at 12 months post-operative without having neurological deficits. Patient refused redo surgery and was advised for continuous external immobilization by Philadelphia cervical collar. 
Table 3. Post-operative clinical outcome of study patients.

\begin{tabular}{ccc}
\hline Post-operative clinical outcome & Number of patients & Percentage \\
\hline $\begin{array}{c}\text { Improved pre-operative cervical } \\
\text { pain and No clinical deterioration }\end{array}$ & $12 / 12$ & $100 \%$ \\
Improved pre-operative & & $57.14 \%$ \\
neurological deficits & $4 / 7$ & $(33.3 \%$ of total study patients $)$ \\
$\begin{array}{c}\text { Stationary course of the } \\
\text { neurological deficits }\end{array}$ & $3 / 7$ & $\begin{array}{c}42.86 \% \\
(25 \% \text { of total study patients })\end{array}$ \\
\hline
\end{tabular}

Table 4. Post-operative radiological outcome of study patients.

\begin{tabular}{ccc}
\hline Post-operative radiological outcome & Number of patients & Percentage \\
\hline Proper reduction and fusion & 11 & $91.7 \%$ \\
Loosening of the screws & 1 & $8.3 \%$ \\
\hline
\end{tabular}

\subsection{Case Presentation}

Case (1): Male patient, 13 years old, had Type II Odontoid fracture following falling from a height (Figure 1).

Case (2): Female patient, 30 years old, had Type II Odontoid fracture following exposure to Road Traffic Accident (RTA) (Figure 2).

Case (3): Male patient, 45 years old, known Rheumatoid arthritis patient developed Type II Odontoid fracture with atlanto-axial subluxation (Figure 3).

\section{Discussion}

There are different management options for treatment of Odontoid fractures. They include external immobilization, anterior Odontoid screw fixation and posterior cervical fusion with or without screw fixation [15] [16]. It will be difficult to choose a management plan in the elderly patients as they usually have osteoporosis, cannot tolerate halo immobilization and have higher surgical complications [17]. Identification of patients with high risk of occurrence of non-union is essential to avoid related possible late complications [18]. Type II fractures have high rates of non-union as most of their patterns of fractures are unstable. Delayed healing at the base of Odontoid due to decreased vascularity is another possible cause [19]. All patients in the current study had type II Odontoid fractures caused by different causes including falls, road traffic accidents and pathological fracture following Rheumatoid arthritis. All patients were complicated by non-union following variable duration from onset of trauma ranging from 1 and 3 years. All patients were managed at first by external immobilization after their first diagnosis with Odontoid fractures for variable duration with partial relief of cervical pain following external immobilization. There are many identified risk factors for non-union in different studies including age above 50 years, fracture displacement and malalignment, base of dens comminution, transverse ligament rupture, Hadley et al. Type IIA, angulation of 10 degrees or more, secondary loss of reduction and delayed treatment [2] [16] [20] [21] [22] [23]. External 


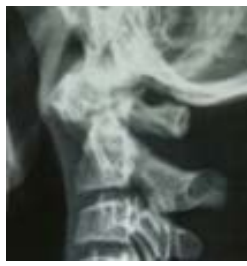

(a)

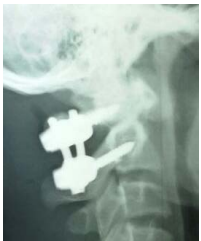

(d)

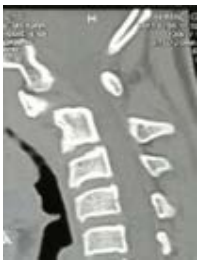

(b)

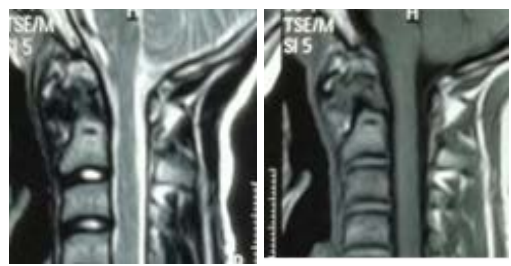

(c)

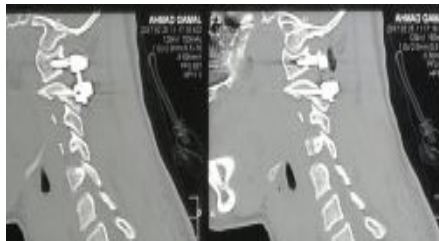

(e)

Figure 1. (a): X-ray cervical spine lateral view showing atlanto-axial subluxation with evidence of odontoid fracture; (b): CT cervical spine, sagittal view showing Type II odontoid fracture with atlanto-axial subluxation; (c): MRI cervical spine, mid-sagittal cuts in both T2 and T1 sequences showing fracture odontoid process with No evidence of myelomalacia; (d): Post-operative X-ray cervical spine lateral view showing proper reduction of the fracture and fixation of $\mathrm{C} 1$ with $\mathrm{C} 2$; (e): Post-operative CT cervical spine sagittal cuts showing proper reduction of $\mathrm{C} 1$ and $\mathrm{C} 2$ with fixation. Axial cuts show proper placement of the screws in both C1 lateral masses and C2 pedicles away from the vertebral arteries foramina. They show also evidence of not performing posterior decompression in this patient (intact posterior arch of $\mathrm{C} 1$ and lamina of $\mathrm{C} 2$ ).

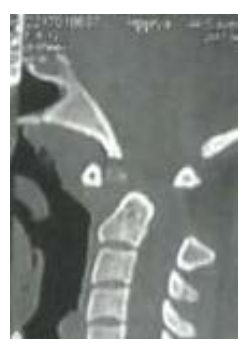

(a)
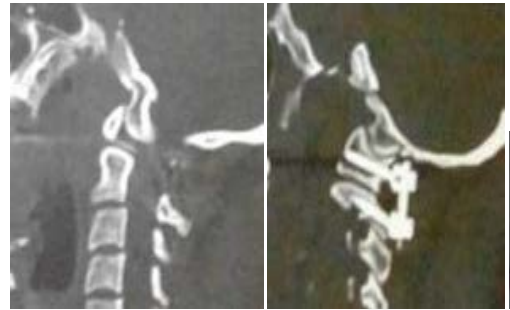

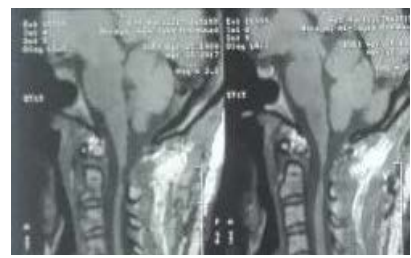

(b)

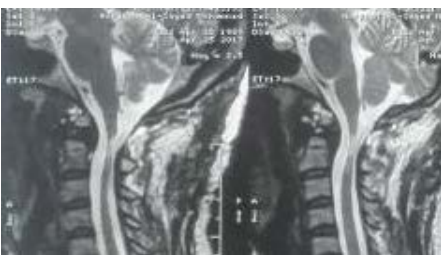

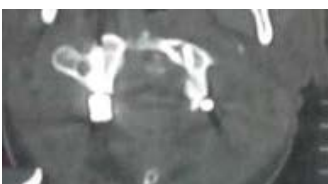

(c)

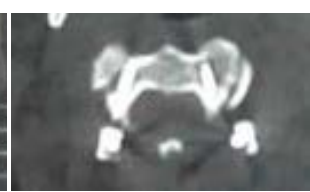

Figure 2. (a): Pre-operative CT cervical spine, sagittal view showing Type II odontoid fracture with atlanto-axial subluxation; (b): MRI cervical spine sagittal view T2 and T1-weighted images midsagittal cuts showing evidence of odontoid fracture, cord compression evidenced by myelomalacia (hyperintense signal intensity within the cord in T2 image and posterior cord compression at T1 image. N.B. It is noted that the body of C2 was reduced during doing MRI and this indicates high grade of instability; (c): Post-operative CT cervical spine cuts (sagittal and axial) showing evidence of posterior decompression of the cord at $\mathrm{C} 1$ and $\mathrm{C} 2$ with proper reduction of the fractured odontoid process and proper placement of the screws in both $\mathrm{C} 1$ lateral masses and $\mathrm{C} 2$ pedicles. 


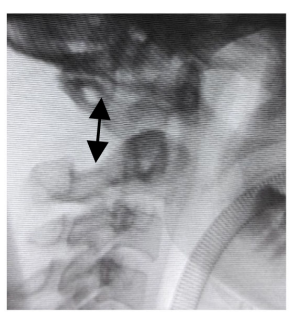

(a)

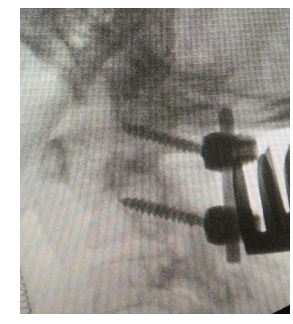

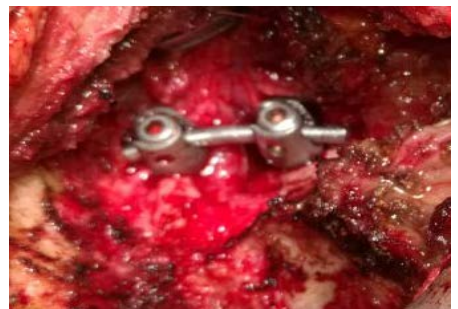

(b)
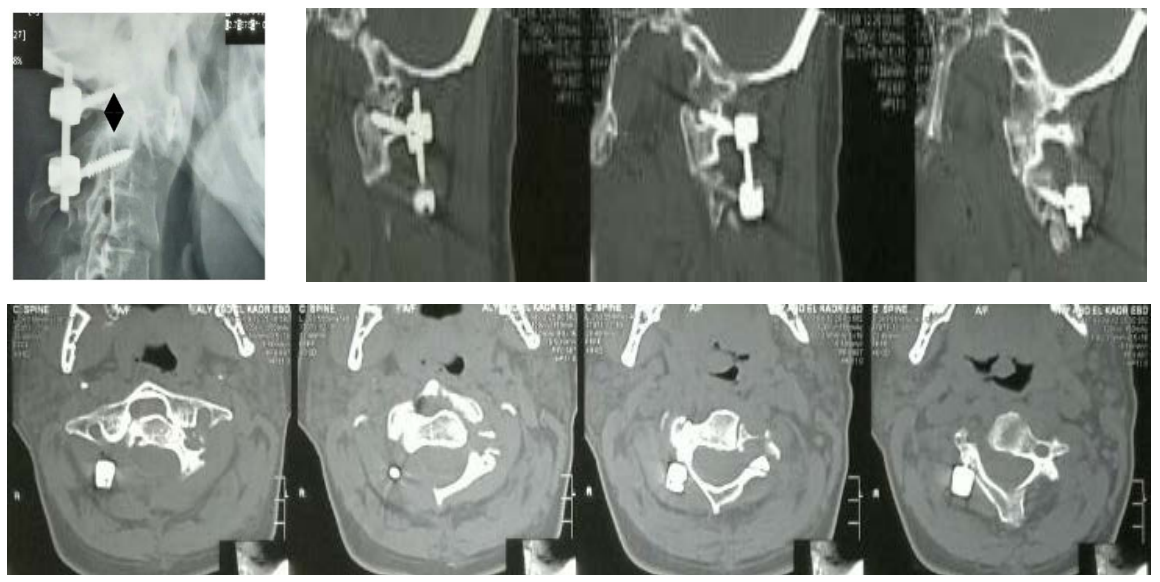

(c)

Figure 3. (a): Pre-operative X-ray cervical spine taken by C-arm intra-operatively showing Type II odontoid fracture with atlanto-axial subluxation (Note widening of the interspinous distance); (b): Intra-operative $\mathrm{X}$-ray cervical spine taken by $\mathrm{C}$-arm showing proper reduction of $\mathrm{C} 1$ to $\mathrm{C} 2$ and other intra-operative photo showing unilateral insertion of fixation system; (c): Post-operative X-ray cervical spine showing proper reduction of odontoid fracture with decrease of interspinous distance to normal (arrowheads). It shows also post-operative CT cervical spine (sagittal and axial cuts) showing partial reduction of odontoid fracture and proper position of screws.

immobilization has a rate of non-union reaching up to $40 \%$ [18]. The most important risk factors of Odontoid non-union seen in all patients in the current study were external immobilization, anxiety and fears from surgical intervention. Other risk factors were age above 50 years (seen in 5 patients), Odontoid displacement (seen in 4 patients), secondary loss of reduction (seen in 3 patients) and delayed treatment (seen in 3 patients) taking into consideration that some patients had more than one risk factor. There are specific considerations in management of Odontoid fractures in the elderly patients especially that these fractures are common in this age group. Both external immobilization and surgical management are associated with high morbidity and mortality with less evident complications and nearly the same outcome with conservative treatment in patients older than 80 years of age [24]. There were no patients above 80 years of age in the current study. All current study patients had failed union of Odontoid fractures with varying degrees of symptoms and neurological status ranging from cervical pain, torticollis, motor and sensory deficits. If non-union follows external immobilization, surgical intervention is advised especially in young patients to prevent late neurological deficits with controversial decision in the 
elderly population due to higher possibility of morbidity in this age group [20]. When surgical management is chosen, Type II Odontoid fractures can be managed by either anterior or posterior approach and both ways are acceptable [25]. Anterior Odontoid screw fixation provides good stability with preservation of most of C1 - C2 motion. It has high efficacy in management of Odontoid fractures with high union rates reaching up to $80 \%-100 \%$ [26]. In addition, with anterior approach bone graft is not required, it is less traumatic and can be used for associated $\mathrm{C} 1$ ring fractures with intact transverse ligament [27]. Anterior approach is indicated with presence of favorable fracture line (from anterosuperior to posterosuperior) together with proper fracture reduction and alignment. It is contraindicated with comminuted fractures, late fractures, severe cervicothoracic kyphosis, severe osteoporosis and ruptured transverse ligament [28] [29]. Short and thick neck of patients are relative contraindications for this approach due to difficulty to reach a suitable trajectory to place the screws in these patients [30]. Best results are obtained when fractures are less than 6 months duration with higher incidence of non-union in older fractures [31]. Anterior Odontoid screw fixation was not suitable for management of the current study patients mostly due to being late fractures. In older patients, there is a higher risk of developing severe dysphagia and early post-operative pneumonia with anterior surgical approach [32]. Posterior approach is usually performed to obtain atlanto-axial joint stabilization. This can be obtained by different methods including wiring and screws. Higher fusion rates are obtained with use of screws [33]. Posterior approach is indicated when anterior approach is contraindicated, with failure of the anterior Odontoid screw fixation, when there is high susceptibility of occurrence of complications from anterior approach like dysphagia and pneumonia especially in elderly, and if the patient has neurological deficit or there is polytrauma [5] [7] [28] [29]. Posterior approach was the approach of choice for the current study patients due to many factors including non-suitable anterior Odontoid screw fixation and presence of neurological deficit in 7 of 12 patients in the current study. The most commonly used posterior C1 - C2 screw fixation are $\mathrm{C} 1$ - $\mathrm{C} 2$ transarticular screws, $\mathrm{C} 1$ lateral mass screw fixation with $\mathrm{C} 2$ screws (through lamina, pars or pedicles) [34] [35]. In the current study, C1 lateral mass and C2 pedicular fixation was the approach of choice with No recorded peri-operative complications in post-traumatic fracture patients. Transarticular screws have many disadvantages including necessity of proper reduction of $\mathrm{C} 1$ on $\mathrm{C} 2$ before insertion of screws, higher risk of vertebral artery injury and associated bleeding during dissection around C2 pedicle [36]. On contrast, C1 lateral mass and C2 pars screws have no evident neurological, vascular or Implant complications with higher fusion rate reaching $100 \%$ [37]. The main advantages of posterior $\mathrm{C} 1$ - $\mathrm{C} 2$ fusion are fewer complications rate and higher fusion rate than anterior Odontoid screw fixation. Its main disadvantages are eliminating the normal $\mathrm{C} 1$ - $\mathrm{C} 2$ rotatory motion and its associated morbidity [31]. The most common complications of posterior approach include blood loss, injury of vertebral artery, dural tears and infection [38]. There is controversy in 
management of Odontoid fractures complicated with atlanto-axial subluxation especially in Rheumatoid arthritis patients complicated by Odontoid fractures and subluxation. The most accepted way of management of these patients is to differentiate between symptomatic and asymptomatic patients. Surgical management will be indicated in symptomatic patients and in asymptomatic patients when dens- $\mathrm{C} 1$ distance is above $8 \mathrm{~mm}$. When surgery is chosen, it will be important to properly reduce the fracture to decompress the upper cord followed by posterior stabilization with or without posterior decompression. The fracture may be not reducible in about $20 \%$ of cases. With irreducible subluxation, odontoidectomy may be indicated. Starting with posterior stabilization is preferred by some surgeons as it may avoid a second operation, and if there is another anterior approach, it will be done while the patient is stabilized. It should be taken into consideration that there may be associated osteoporosis and softening of bones in patients with Rheumatoid arthritis and extra-care should be taken while operating such patients to avoid iatrogenic more added bony fractures and subsequent neurological deficits [39]. In the current study, we started with posterior approach in all study patients. Posterior cord decompression was done in 4 patients with severe cord compression in an attempt to improve the clinical outcome. This was followed by intra-operative reduction under $\mathrm{x}$-ray guidance using C-Arm. This was the chosen way in our study and it was successful in all study cases with good full reduction in 11 patients and partial accepted reduction in 1 (Rheumatoid arthritis) patient with No recorded intra-operative or early post-operative complications caused by using this approach for reduction. Posterior stabilization through $\mathrm{C} 1$ lateral mass- $\mathrm{C} 2$ pedicle screws was the chosen way for C1 - C2 stabilization and it was successful in 11 patients to stabilize the subluxated vertebrae and permanently fuse them with failure in 1 (Rheumatoid arthritis) patient after 1 year of follow up due to loosening of the inserted unilateral screws. There was good clinical and radiological outcome with using this approach in management of atlanto-axial subluxation caused by neglected Type II Odontoid fractures. There was no need for subsequent anterior approach and odontoidectomy in all patients except in Rheumatoid arthritis patient. Additional posterior decompression was helpful in improvement of the clinical outcome in 2 of 4 selected patients with severe cord compression and no difference was observed in the other 2 . This indicates that posterior decompression may be helpful in improving the clinical outcome in patients with severe cord compression. Rheumatoid arthritis patient in this study was candidate for surgical intervention as he was symptomatic and had radiological evidence of subluxation. Posterior approach was used at first as posterior compression caused by subluxation was more evident than anterior compression caused by pannus aiming for proper reduction and posterior stabilization with post-operative reassessment for need for anterior trans-oral approach. Intra-operatively, there was good reduction of the fracture and associated subluxation but bony softening and osteoporosis on Left side of C1 and C2 were observed and unilateral fixation was done. Posterior decompression was not cho- 
sen fearing of development of more instability at $\mathrm{C} 1$ - C2. With radiological follow up, there was still anterior compression and so, a second anterior surgery was planned for but this was met by patient refusal. At 12 months follow up, there was evidence of loosening of the screws which necessitate surgical revision which was also refused by the patient and so, he was advised for permanent use of Philadelphia cervical collar.

\section{Limitations}

Limitations in this study included little number of the study patients, different age groups, variable duration from trauma onset and different clinical presentations that make it difficult to get more accurate conclusive results. Post-operative follow up period was ending at 12 months after surgery making it difficult to detect possible late mechanical complications of implants like loosening or breaks. Some of these limitations were related to Rheumatoid arthritis patient including incomplete management course and missed some radiological images. They also included lack of doing routine pre-operative $\mathrm{CT}$ angiogram to rule out vascular causes of neck pain including arterial dissection and to obtain pre-operative mapping of vertebral arteries. However, there were no recorded complications in the study patients related to vertebral artery injuries. Lack of pre-operative experimental setups was another limitation in this study. Late follow up images of representative cases at 3, 6 and 12 months were not presented in the study as there were no differences between them and early post-operative images.

\section{Conclusion}

Type II Odontoid fractures have higher rates of developing non-union when managed conservatively with external immobilization. If non-union occurs, surgical management should not be delayed especially if there are associated neurological deficits. Intra-operative reduction under X-ray C-Arm with posterior C1 - C2 fixation is an accepted method for management of neglected type II Odontoid fractures with good fusion rate and low rate of complications. The presence of higher grades of weakness (Grade 3 or more) and evidence of myelomalacia in MRI images are associated with less favorable clinical outcome. Addition of posterior cord decompression may be an option to improve clinical outcome in patients with severe cord compression. Patients with Rheumatoid arthritis complicated with Odontoid fractures should be carefully evaluated before proceeding to surgery for presence of pannus and bone softening.

\section{Conflicts of Interest}

The authors declare no conflicts of interest regarding the publication of this paper.

\section{References}

[1] Malik, S.A., Murphy, M., Connolly, P. and O’Byrne, J. (2008) Evaluation of Morbid- 
ity, Mortality and Outcome Following Cervical Spine Injuries in Elderly patients. European Spine Journal, 17, 585-591. https://doi.org/10.1007/s00586-008-0603-3

[2] Hanigan, W.C., Powell, F.C., Elwood, P.W. and Henderson, J.P. (1993) Odontoid Fractures in Elderly Patients. Journal of Neurosurgery, 78, 32-35.

https://doi.org/10.3171/jns.1993.78.1.0032

[3] Marchesi, D.G. (1997) Management of Odontoid Fractures. Orthopaedics, 20, 911-916.

[4] Ryan, M.D. and Henderson, J.J. (1992) The Epidemiology of Fractures and Fracture Dislocations of the Cervical Spine. Injury, 23, 38-40.

https://doi.org/10.1016/0020-1383(92)90123-A

[5] Kutbe, S. (2017) Treatment of Odontoid Fractures: A Clinical Challenge and Reality. National Journal of Clinical Orthopaedics, 1, 10-15.

[6] Vaccaro, A.R., Madigan, L. and Ehler, D.M. (2000) Contemporary Management of Adult Cervical Odontoid Fractures. Orthopedics, 23, 1109-1113.

https://doi.org/10.3928/0147-7447-20001001-11

[7] Anderson, L.D. and D'Alonzo, R.T. (1974) Fractures of the Odontoid Process of the Axis. Journal of Bone \& Joint Surgery, 56, 1663-1674. https://doi.org/10.2106/00004623-197456080-00017

[8] Patel, A., Smith, H.E., Radcliff, K., Yadlapalli, N. and Vaccaro, A.R. (2012) Odontoid Fractures with Neurological Deficits Have Higher Mortality and Morbidity. Clinical Orthopaedics and Related Research, 470, 1614-1620. https://doi.org/10.1007/s11999-011-1994-8

[9] Grauer, J.N., Shafi, B., Hilibrand, A.S., Harrop, J.S., Kwon, B.K., Beiner, J.M., et al. (2005) Proposal of a Modified Treatment-Oriented Classification of Odontoid Fractures. The Spine Journal, 5, 123-129. https://doi.org/10.1016/j.spinee.2004.09.014

[10] Bohler, J. (1982) Anterior Stabilization for Acute Fractures and Non-Unions of the Dens. Journal of Bone \& Joint Surgery, 64, 18-27.

https://doi.org/10.2106/00004623-198264010-00004

[11] Brooks, A.L. and Jerkins, E.B. (1978) Atlanto-Axial Arthrodesis by the Wedge Compression Method. Journal of Bone \& Joint Surgery, 60, 279-284. https://doi.org/10.2106/00004623-197860030-00001

[12] Coyne, T.J., Fehlings, M.G., Wallace, M.C., Bernstein, M. and Tator, C.H. (1995) C1-C2 Posterior Cervical Fusion: Long-Term Evaluation of Results and Efficacy. Neurosurgery, 37, 688-692. https://doi.org/10.1227/00006123-199510000-00012

[13] Hadley, M.N., Browner, C.M., Liu, S.S. and Sonntag, V.K.H. (1988) New Subtype of Acute Odontoid Fractures (Type IIA). Neurosurgery, 22, 67-71. https://doi.org/10.1227/00006123-198801000-00010

[14] Shears, A. and Armistead, C.P. (2008) Surgical versus Conservative Management for Odontoid Fractures. Cochrane Database of Systematic Reviews, 4, Article ID: CD005078. https://doi.org/10.1002/14651858.CD005078.pub2

[15] Denaro, V., Papalia, R., Di Martino, A., Denaro, L. and Mafulli, N. (2011) The Best Surgical Treatment for Type II Fractures of the Dens Is Still Controversial. Clinical Orthopaedics and Related Research, 469, 742-750.

https://doi.org/10.1007/s11999-010-1677-x

[16] Joaquim, A.F. and Patel, A.P. (2010) C1 and C2 Spine Trauma. Evaluation, Classification and Treatment. Contemporary Spine Surgery, 11, 1-7. https://doi.org/10.1097/01.CSS.0000369159.82865.84 
[17] Muller, E.J., Wick, M., Russe, O. and Muhr, G. (1999) Management of Odontoid Fractures in the Elderly. European Spine Journal, 8, 360-365. https://doi.org/10.1007/s005860050188

[18] Robinson, Y., Robinson, A.L. and Olerud, C. (2014) Systematic Review on Surgical and Nonsurgical Treatment of Type II Odontoid Fractures in the Elderly. BioMed Research International, 2014, Article ID: 231948. https://doi.org/10.1155/2014/231948

[19] Govender, S., Maharaj, J.F. and Haffajee, M.R. (2000) Fractures of the Odontoid Process. The Journal of Bone and Joint Surgery, 82B, 1143-1147. https://doi.org/10.1302/0301-620X.82B8.0821143

[20] Hadley, M.N., Browner, C. and Sonntag, V.K. (1985) Axis Fractures: A Comprehensive Review of Management and Treatment in 107 Cases. Neurosurgery, 17, 281-290. https://doi.org/10.1227/00006123-198508000-00006

[21] Greene, K.A., Dickman, C.A., Marciano, F.F., Drabier, J.B., Hadley, M.N. and Sonntag, V.K. (1997) Acute Axis Fractures. Analysis of Management and Outcome in 340 Consecutive Cases. Spine, 22, 1843-1852.

https://doi.org/10.1097/00007632-199708150-00009

[22] Platzer, P., Thalhammer, G., Sarahrudi, K., Kovar, F., Vekszler, G., Vecsei, V., et al. (2007) Nonoperative Management of Odontoid Fractures Using a Halothoracic Vest. Neurosurgery, 61, 522-530. https://doi.org/10.1227/01.NEU.0000290898.15567.21

[23] Hadley, M.N., Dickman, C.A., Browner, C.M. and Sonntag, V.K.H. (1989) Acute Axis Fractures: A Review of 229 Cases. Journal of Neurosurgery, 71, 642-647. https://doi.org/10.3171/jns.1989.71.5.0642

[24] Smith, H.E., Kerr, S.M., Maltenfort, M., Chaudhry, S., Norton, R., Albert, T.J., et al. (2008) Early Complications of Surgical versus Conservative Treatment of Isolated Type II Odontoid Fractures in Octogenarians: A Retrospective Cohort Study. Journal of Spinal Disorders \& Techniques, 21, 535-539. https://doi.org/10.1097/BSD.0b013e318163570b

[25] Ryken, T.C., Hadley, M.N., Aarabi, B., Dhall, S.S., Gelb, D.E., Hurlbert, R.J., et al. (2013) Management of Isolated Fractures of the Axis in Adults. Neurosyegery, 72, 132-150. https://doi.org/10.1227/NEU.0b013e318276ee40

[26] Dailey, A.T., Hart, D., Finn, M.A., Schmidt, M.H. and Apfelbaum, R.I. (2010) Anterior Fixation of Odontoid Fractures in an Elderly Population. Journal of Neurosurgery, 12, 1-8. https://doi.org/10.3171/2009.7.SPINE08589

[27] Grauer, J.N., Vaccaro, A.R., Beiner, J.M., Kwon, B.K., Hilibrand, A.S., Harrop, J.S., et al. (2004) Similarities and Differences in the Treatment of Spine Trauma between Surgical Specialties and Location of Practice. Spine, 29, 685-696. https://doi.org/10.1097/01.BRS.0000115137.11276.0E

[28] Agrillo, A., Russo, N., Marotta, N. and Delfini, R. (2008) Treatment of Remote Type II Axis Fractures in the Elderly: Feasibility of Anterior Odontoid Screw Fixation. Neurosurgery, 63, 1145-1151. https://doi.org/10.1227/01.NEU.0000335780.87219.E9

[29] Henry, A.D. and Bohly, J. (1999) Grosse A: Fixation of Odontoid Fractures by an Anterior Screw. The Journal of Bone and Joint Surgery, 81B, 472-477. https://doi.org/10.1302/0301-620X.81B3.0810472

[30] Esses, S.I. and Bednar, D.A. (1991) Screw Fixation of Odontoid Fractures and Nonunions. Spine, 16, S483-S485. https://doi.org/10.1097/00007632-199110001-00005

[31] Apfelbaum, R.I., Lonser, R.R., Veres, R. and Casey, A. (2000) Direct Anterior Screw 
Fixation for Recent and Remote Odontoid Fractures. Journal of Neurosurgery, 93, 227-236. https://doi.org/10.3171/spi.2000.93.2.0227

[32] Vasudevan, K., Grossberg, J.A., Spader, H.S., Torabi, R. and Oyelese, A.A. (2014) Age Increases the Risk of Immediate Postoperative Dysphagia and Pneumonia after Odontoid Screw Fixation. Clinical Neurology and Neurosurgery, 126, 185-189. https://doi.org/10.1016/j.clineuro.2014.09.006

[33] Elgafy, H., Dvorak, M.F., Vaccaro, A.R. and Ebraheim, N. (2009) Treatment of Displaced Type II Odontoid Fractures in Elderly Patients. American Journal of Orthopedics, 38, 410-416.

[34] Magerl, F.S.C.S. and Seeman, P.S. (1987) Stable Posterior Fusion of the Atlas and Axis by Transarticular Screw Fixation. In: Kehr, P. and Weidner, A., Eds., Cervical Spine I, Springer-Verlag, New York, 322-327.

https://doi.org/10.1007/978-3-7091-8882-8_59

[35] Joaquim, A.F., Ghizoni, E., Anderle, D.V., de Oliviera, E. and Tedeschi, H. (2012) Axis Instrumentation: Surgical Results. Arquivos de Neuro-Psiquiatria, 70, 857-863. https://doi.org/10.1590/S0004-282X2012001100007

[36] Harms, J. and Melcher, R.P. (2001) Posterior C1-C2 Fusion with Polyaxial Screw and Rod Fixation. Spine, 26, 2467-2471.

https://doi.org/10.1097/00007632-200111150-00014

[37] Melcher, R.P., Puttlitz, C.M., Kleinstueck, F.S., Lotz, J.C., Harms, J., et al. (2002) Biomechanical Testing of Posterior Atlantoaxial Fixation Techniques. Spine, 27, 2435-2440. https://doi.org/10.1097/00007632-200211150-00004

[38] Smith, H.E., Vaccaro, A.R., Maltenfort, M., Albert, T.J., Hilibrand, A.S., Anderson, D.G., et al. (2008) Trends in Surgical Management for Type II Odontoid Fracture: 20 Years of Experience at a Regional Spinal Cord Injury Center. Orthopedics, 31, 650-655.

[39] Papadopoulos, S.M., Dickman, C.A. and Sonntag, V.K.H. (1991) Atlantoaxial Stabilization in Rheumatoid Arthritis. Journal of Neurosurgery, 74, 1-7.

https://doi.org/10.3171/jns.1991.74.1.0001 